\title{
FRONTIER CITIZENSHIP AND STATE FRAGILITY IN KENYA
}

\section{J. Ododa OPIYO}

\begin{abstract}
Insecurity is a major problem amongst the nomadic communities in North western Kenya. The communities include the Pokots, Turkana, Marakwet, Toposa and Karamoja. Using the Pokot Community as a case study of nomadic life style, this paper examines the environmental constraints, cattle rustling and small arms as triggers of Pokot community movements into their frontiers; -zones of contact of states or communities. In search of water and pasture, the Pokot traverse their frontiers and interact socially, economically and environmentally with their neighbours. The movements expose their cattle and property to banditry and cattle rustling. The Pokots thus acquire small arms to protect their livestock and property even though the acquisition of and stocking of arms is the responsibility of the government. So the acquirement of small arms by the Pokot creates a fragile insecurity situation characterised by cattle rustling and banditry. As Kenyan citizens, the Pokots have a social contract with the state to provide security but this is not the case because of the transitional nature, as nomads. Insecurity to the nomadic communities manifests in terms of environmental, natural resource based and identity based conflicts. It is concluded that addressing insecurity in this region has to lessen banditry, cattle rustling, social underdevelopment and negative ethnicity. The steps towards solving state fragility and insecurity ought to take cognizance of the interactions between frontier citizens, environmental constraints, traditions, politics and acquisition of small arms.
\end{abstract}

\section{Introduction}

The itinerant Pokot Community, who own large numbers of cattle, live in north western Kenya. Their nomadic tendencies are normally triggered by, among other things, scarcity of pasture and water for their cattle. Their life is informed by harsh weather patterns characterized by temperatures of over 40 degrees centigrade and a rainfall of less than $500 \mathrm{~mm}$ (per annum). To survive, the Pokot have built coping mechanisms that revolve around movement to and from water points and pastures. In their mind set, the Pokot consider the localities that they traverse as their frontiers. ${ }^{1}$ Consequently, the Pokot consider the grazing areas in North-western Kenya and Eastern Uganda as their frontiers. However, as they lay claim to these frontiers, insecurity in terms of cattle rustling and conflicts over the scarce resources emerge.

Cattle rustling and banditry activities involve organized armed raids which often result into human deaths and loss of livestock. The Pokot consider cattle rustling as traditional and

1 See FN 3, below for the definition of frontiers. 
customary and is therefore an important identity issue which informs the community reproduction process. ${ }^{2}$ Most profound though is the need for the Kenyan government to provide security for the community and their cattle as they traverse 'their' frontiers. This has not been forthcoming prompting the community to illegally acquire fire arms to secure themselves and their livestock. The small arms, in the interpretation of the Pokot, are used for defence against external aggression. The notion of external aggression here implies any attacks from the other communities around this region, such as the Marakwet, the Turkana or the Karamoja (from Uganda). Using the Pokot as a representative case of the nomadic communities, this paper examines the environmental constraints that trigger the movements, cattle rustling and small arms proliferation and how these increase the chances for insecurity. The paper concludes by suggesting a number of approaches that may be followed to alleviate the insecurity problems of the Pokot community.

\section{Frontiers and Frontier Citizenship}

Frontiers are zones of contact of a state or community. Frontiers radiate from a given state or community so that the inner limits touch on the neighbouring states or communities, the outer limits of frontiers of any given state go far beyond the proximate and immediate neighbours. Frontiers are divided into two; the internal frontiers and external frontiers. Internal frontiers are zones of contact within sovereign states while external frontiers go beyond state boundaries. Indigenous communities such as the Pokot and Turkana identify themselves with both internal and external frontiers without considering territorial borders. ${ }^{3}$

In examining the frontiers of the states it is realised that the states in Africa are a design of the Westphalia state system, and this has had critical implications on their international relations. The new states had to establish state frontiers immediately upon independence in order to practise and project their influences. The problem here is that state frontiers do not respect internal frontiers ${ }^{4}$. Again, the interaction within internal frontiers and state frontiers is extremely complex due to the rules and laws observed by states. In Africa, the inherited borders from the colonial (administration) legacy are inviolable. The defunct Organization of African Unity (OAU) Charter Article 3 (2) stipulated that "member states solemnly affirm and declare their respect for the sovereignty and territorial integrity of each state for its inviolable right to independence." 5 The argument here is that borders acquired at independence are to remain uti

2 Cattle rustling, as a tradition enables young Pokots to acquire cattle, which they pay as bridal price. For the young men who do not have enough cattle to pay as bride price, it is impossible to get married and therefore stands a possibility of being extinct. Those who have excess cattle go further and become polygamous and therefore reproduce offspring more than the poor ones without cattle.

3 See for example Taylor, P.J., Political Geography: World Economy, Nation State and Locality (New York: Longman, 1985), p. 145.

$4 \quad$ Ibid.

5 The OAU Charter, Article 3(2), African Union (AU) maintains the same position in Article 4 (a), (b) and (g). However the AU accepts intervention in article $4(\mathrm{~h})$. which states: the right of the Union to intervene in a member state pursuant to a decision of the Assembly in respect of grave circumstances, namely war crimes, genocide and crimes against humanity. For details see the Constitutive Act of the African Union Article 4, done at Lome Togo, on 11th July 2000. 
possidetis. The acceptance of the borders is based on the fear that if issues of borders are allowed to change; many other cases would come up, hence causing conflicts. To allow any changes of the borders of a state or states would lead to similar demands among other contested boundaries elsewhere. ${ }^{6}$ Most of the African states have accepted the inherited borders and advocate that they be retained. ${ }^{7}$ While matters that occur within the internal frontiers are considered internal affairs of states, territorial borders that delimit states are so porous to economic, social and cultural activities that they hardly restrict movements of persons.

As the Pokot traverse their frontiers and interact socially, economically and environmentally, they cross the international border between Kenya and Uganda. When the Pokot come back to Kenya, they carry arms across the borders, an illegal action that creates a fragile security situation in the region. On many occasions, banditry activities have been associated with the cross frontier movements. The Pokot, as frontier citizens, require security provided by both governments of Kenya and Uganda. This is not the case because the pokots as frontier citizens are transitional. The security providers such as the Police are in static stations while the Pokots change their locations into their frontiers depending on where there is availability of water or pasture. It is hard for the police to keep pace in order to provide adequate security. The security situation in the Pokot area therefore shows disequilibrium between the expectation of the community and the reality about provision of security by the state. As citizens, the Pokot have a social contract with the state that entails a number of issues. While the Pokot community expects the government to provide security, Kenya government ought to exhibit legitimacy in shaping the expectations of this community and further shape the political environment to enable them practise their frontier citizenship. Unfortunately, this is not the case in North-western Kenya.

The acquisition of arms by the Pokot means a competing location of authority in North-western Kenya, a fragile environment for the security of Kenya, and questionable legitimacy and accountability of the state in the Pokot (community) areas. Even if the Pokot were to address the incapacity of the government to provide security, there is lack of political processes through which the community can bargain with the state. The situation in north western Kenya provides for the conditions of a fragile state which is when state structures lack political will and or/capacity to provide the basic functions needed for security, development, poverty reduction, and human rights. ${ }^{8} \quad$ Kenya is not a failed state but may be classified as a divided state, one which manifests substantial divisions between national, ethnic and religious groups. In these circumstances, Kenya has not been able to meet its population expectations or manage changes in the expectations through political processes.

\footnotetext{
6 Oduogo Cyprine Onyango' 'Territorial Claim as the Model Determinant of Inter-State Conflicts Between Ethiopia and Somalia, 1960-1991' in P. Godfrey Okoth \& Bethwell A. Ogot, (ed.), Conflict in Contemporary Africa (Nairobi: Jomo Kenyatta Foundation, 2000), pp. 82-93:82.

7 See for example Saadia Touval, The Boundary Politics of Independent Africa (New Haven: Harvard University Press, 1972).

8 See for example OECD/DAC, The principles for good international engagement in fragile states and situations, Paris, 2007 and OECD/DAC, Concepts and Dilemmas of state building in fragile situations, Off-Print of the Journal of Development, 2008, pp 17-18.
} 


\section{Frontiers of the Pokot Community and State Fragility}

The Pokot belong to the southern nilotes people. Some Pokots live in the dry plains subsisting by livestock keeping while others live in the mountain region and depend on farming. ${ }^{9}$ They are both pastoralists and agriculturalist. Though found at the border of Kenya and Uganda, most of them live in Uganda. In Kenya, they occupy the West Pokot district, which borders Uganda to the west, Turkana district to the East, Baringo to the South-east, and Marakwet and Trans Nzoia districts to the south.

The immediate internal frontiers of Pokot community in terms of districts are Samburu, Laikipia, Baringo, Uasin Gishu, Bungoma and Kipsigis districts. However, the community's external frontiers extend beyond territorial borders of Kenya to Uganda, Sudan and Ethiopia. It is here that the cobweb nature of interactions of communities is evident. If for instance Pokot raids their next door neighbours the Marakwet, they move into Uganda transforming Kenyan internal affairs into internationalised ones. Consequently, reclaiming such cattle requires that the Kenyan security organs request permission from Ugandan government. This phenomenon repeats itself whenever Pokots from Uganda raid their neighbours and cross over into Kenya. What emerges is a series of conflict and cooperation in an environment that is extremely fragile.

In a democratic state, just like all sovereign states, the government is supposed to provide law and order and when this is not the case, a security problem arises. Based on a critical evaluation, one can locate the threats and vulnerabilities of frontier citizens. The existential threats to a state, for example, normally involve matters of sovereignty, because it is sovereignty that defines a state as one. Moreover, sovereignty is about providing security and maintaining order, certain level of legitimacy on all traits of governance and claim to ultimate right of self-government. ${ }^{10}$ The ultimate right of self-government presents a situation in which the leadership and instruments of leadership must be evident in all parts of a state. Where this is not the case then there is a major insecurity problem.

In any independent state, a number of security concerns arise; first there must be evidence of legitimacy and assurance of protection in order to avoid state fragility and insecurity. The protection against threats is the responsibility of a government, thus if this is not the case, then it becomes difficult to claim that the state is performing its responsibilities. In north western Kenya, the state has in many occasions failed to protect its citizens from attacks by bandits and cattle rustlers. Political climate for a long time has been partisan, because communities that do not support the regime in power are denied the development required. In enlisting support, the political parties of the day instil fear on those who dissent. During national elections, for example, the government instigates fighting amongst the communities. The evidence of

\footnotetext{
9 K. Kuvita, 'Material Culture of the Pokot in Kenya: With Special Reference to Circulation of Articles' In African Study Monograph Supplementary Issue No. 3, (1983).

10 For a discussion on the normative framework of sovereignty see for example, Francis M. Deng, Sadikiel Kimaro, Terrence Lyons, Donald Rothchild, and I. William Zartman, Sovereignty as Responsibility: Conflict Management in Africa (Washington D.C.: The Brookings Institution, 1996), pp. 1-33.
} 
government involvement cannot be underrated as Colin Kahl observes while explaining the attacks that earmarked the Moi regime:

“The attacks were surprisingly similar, suggesting coordination by elites. In most instances hundreds of so called Kalenjin warriors attacked the farms of nonKalenjin, looted and burned houses, and killed and terrorised their inhabitants. The attackers typically dressed in an informal uniform of shorts and red or black T-shirts (Some marked their faces with clay) and they consistently armed with the traditional weapons, including bows, arrows, spears shields, pangas, and later homemade guns. Available evidence also suggests that a number of prominent national and local KANU officials went so far as to directly support attackers by providing training, transportation, and some times payment."

Government involvement in instigating violence during Moi’s leadership was rampant especially after he realised that he could not resist calls for political pluralism. KANU politicians, mostly from the Kalenjin and Maasai communities, began to call for the forced eviction of other ethnic communities from their midst in the Rift Valley. ${ }^{12}$

\section{Triggers of Violence: Environmental Constraints and Security}

As the Pokot move across their frontiers, both imagined and physical, three types of conflicts which normally translate to violence are discernible. These are the environmental conflicts, natural resource-based conflicts, and identity-based conflicts. This section examines the implications of the environmental and natural resource based constraints in North-western Kenya.

Environmental conflicts and overt violence are common in pastoral community areas. The environmental conflicts emanate from extravagant tendencies in the utilisation of natural resources, which have negative consequences on the environment. Thus environmental conflicts arise when different communities have incompatible goals about the utilisation of certain natural resources. ${ }^{13}$ For example, at Tot, an administrative division in Marakwet district, the Marakwet community build their homes on the mountain slopes to give opportunity for families to farm the lowlands. The lowlands are not inhabited completely except for small manyattas ${ }^{14}$ for keeping goats and sheep. During drought, the Pokot easily go into their neighbours' farms and graze on the crops. The Marakwet forcefully respond to this wanton aggression by repelling the Pokots or killing their livestock. ${ }^{15}$ Typically, violence starts by individual Pokot herders' desire to utilise pastures in such a manner that would only benefit them. As they use it individually, they collaborate with the rest of their community members. Nevertheless, as the utilisation changes

\footnotetext{
11 Kahl, Colon H., States, Scarcity and Civil Strife in Developing World (Princeton: Princeton University Press, 2000), pp. 117-162:123.

12 Ibid., p. 142.

13 M. Mwagiru, Peace and Conflict management in Kenya (Nairobi: Pann Printers, 2003), pp. 55-62.

$14 \quad$ Manyattas are makeshift homesteads of pastoral communities.

15 Interview with Mr. Chebet on the issues of environmental conflicts between Pokots and Marakwets on 19 Sept 2007 at Kapsowar, Marakwet District Headquarters.
} 
from individual to community, there are possibilities of resource over-exploitation. The fear and threat of possible resource exhaustion breeds fear and hence pressure on resources, leading to movements into the frontiers.

As the communities exhaust pasture and water within their internal frontiers, they infringe in what other communities in Uganda and Ethiopia consider as theirs. Indeed, matters of the environment also know no borders. Naturally then, there appears to be a correlation between environmental conflicts domestically and internationally. For instance, an insecurity issue that starts locally easily translates to the sub region and ultimately international levels.

For the Pokot community, in a period of one year, there appears to be a cycle of environmental conflicts revolving around pasture. During the rainy season, there is a lot of pasture and consequently peace. During periods of drought, there is heightened competition over use of pastureland. As the Pokot realise that other communities such as the Turkana and Samburu also stand to utilise the same pasturelands, the potential for conflict becomes greater. Intense competition over the utilization of the natural resources at this stage becomes a serious insecurity issue as the other communities' utilization threatens the survival of the Pokot as a community.

As the communities scavenge for pasture in their frontiers cattle raids intensify for two reasons. First, the frontier movements expose the cattle to raiders, and secondly, during the dry season, most of the cattle die creating the need for replenishment. The situation stabilises during the next rainy season. This description tallies well with what Mwagiru calls, environmental conflict cycle, in which the analysis circle is divided into two parts. The first part is the potential stage that includes latent and incipient environmental conflicts and secondly the manifest stage which includes acknowledgement and overt stages. ${ }^{16}$

Drought-related violence also manifests at a number of levels to include that of grazing and water sources for animals; at the level of availability of food for human beings; and at the level of the destruction of the environment. The wastage of the environment causes natural resourcebased conflict. However, because the environment knows no frontiers, the environmental conflicts affect the whole system. Conflicts between Pokot and other communities about the scarce natural resources in the last decade have been the worst humanitarian crisis in modern Kenya. Without adequate water and pasture, frequent cattle raids are experienced in the region. ${ }^{17}$ The raids become bloodier as desperate pastoralists try to sustain their herds. Other communities in North-western Kenya such as the Marakwet depend on rivers to irrigate their farms. One of the major rivers borders Pokot territory and sharing this water resource has made it a major battleground between the two communities, one fighting to irrigate farms, the other to water livestock.

\section{Cattle rustling and Small Arms}

Cattle rustling is the stealing of domestic livestock such as cattle, goats, sheep, donkeys and camels either stealthily or violently. Traditionally, young men who seek bride wealth would in certain circumstances steal livestock from their neighbours in the event that the groom's family was too poor to advance the livestock to the young man seeking to start a family of his own. For

16 See for example M. Mwagiru, Peace and Conflict Management in Kenya, op. cit. p. 55.

17 The Editor, Disaster Relief Organization; DisasterRelief.Org. http:/ / wmw. disasterrelief.org accessed on 6 September 2010. 
centuries, cattle raids by Pokots and Marakwets have been a traditional method of replenishing herds in the wake of drought and disease. ${ }^{18}$ Traditionally, it is considered a legitimate activity whose execution is approved and consented to by community elders ${ }^{19}$. Cattle raiding, the Pokot say, is an important way to show and to achieve prestige, and for stockless men (men without cattle), the only way to earn bride price and enter an independent pastoral existence. ${ }^{20}$ However, the proliferation of the modern and sophisticated automatic weapons has, quietly and negatively exacerbated the consequences of cattle rustling. ${ }^{21}$ Even though cattle rustling could be associated with tradition and therefore identity, the practice has evolved differently in the recent past. Cattle rustling is today associated with killings and politics. ${ }^{22}$ In post-modern Kenya, cattle rustling has transformed from being a customary means of livestock restocking where traditional weapons such as bows and arrows and spears were used to a commercial practice where sophisticated weaponry is used. ${ }^{23}$

The modern firearms have complicated the way cattle raids are contacted today. While the philosophy of war among the Marakwets abstains from killing women and children, the Pokots in their attacks kill everything including innocent children and women, who otherwise would eventually give birth to future enemies. Children, preferably girls, from the other side are captured as booty to decrease the 'enemy's' population. ${ }^{24}$ In the past, cattle rustling was accepted by elders, but with the advent of small arms, it has become unnecessarily brutal and lethal. The following narration illustrates the brutality. 'One Sunday morning, the Pokots attacked Tot health centre during a polio vaccination. In this attack about 12 children died not by bullet wounds only but most were crushed using stones.'

Insecurity in this area has had devastating effects on the lives of the inhabitants creating a very fragile situation. In Tot division, schools (such as Kilang'ata primary) were closed in 2002 and have never been reopened. Farming has nearly grounded to a halt. This insecure environment has triggered rural-urban migration in which the Marakwet have settled in other peaceful areas especially in Eldoret, about $189 \mathrm{~km}$ away with negative consequences on the development of both Pokot and Marakwet districts. The Marakwet District Officer I (DOI) Mr. Gicheru argues that there is need to encourage development oriented policies to enable the Marakwet and Pokot

18 USAID, Greater Horn of Africa Peace Building Project: Assessment and Programmatic Recommendations: Addressing Pastoralist Conflict in the Karamoja Cluster of Kenya, Uganda and Sudan, (Washington D.C: Management Systems International, 2002).

19 Interview with Mzee Joshua Lang'at, 77 years old and a member of a two year old Marakwet Council of Elders, 20 Sept 2007.

20 Cattle rustling is an identity issue, the Pokot community here are extremely involved in cattle rustling to an extent that even if they are educated, they still participate in cattle raids.

21 M. Boking, Outline of Pre-colonial Eastern Pokot History, (Institute of African Studies: University of Nairobi, 1998).

22 Interview with father Walters Kibet, a catholic priest at Kapsowar Parish at Kapsowar, 20 Sept 2007.

23 The Standard, Nairobi, Kenya Friday, September 3, 2010, p.13.

$24 \quad$ Interview with Father Walters Kibet, op cit. 
to do sedentary farming rather than pastoralism to reduce or bring to a stop incidences of cattle raids. $^{25}$

The insecurity in southern Ethiopia, Somalia, Sudan and Eastern Uganda, has led to an influx of firearms into North-western Kenya, raising the possibility of more conflicts. In a society that a generation ago relied on spears to beat back rivals who attacked with poisoned arrows, the assault rifle has become the weapon of choice in terms of banditry activities. Both Presidents Kenyatta and Moi regimes armed the Pokots to act as a buffer from external raiders emanating from neighbouring countries. However, the community has turned the same guns against their immediate neighbours. Others get these arms from illegal gun markets in Kenya which find their way from as far as US and China through war zones in neighbouring countries. ${ }^{26}$

Insecurity escalated when the government gave arms to Pokot police reserves and home guards. The arms were often used not for intended purposes but for cattle rustling. For instance, the Elmo of the Marakwet community suffered in the hands of Pokots not because they did not know how to fight but because they used arrows against modern weaponry. There was evidence of the Pokot training in small arms tactics, a training undertaken by their kinsmen actively serving in the regular military and paramilitary forces, Kenya Army, General Service Unit (GSU) and the Kenya Police. ${ }^{27}$ Besides encouraging and promoting cattle rustling, small arms also increased the amount of raids and crime in Pokot and Marakwet border areas. Incidences of carjacking and home break-ins became extremely common. ${ }^{28}$ The various attacks led Marakwets to start acquiring arms especially from captured or killed Pokots. To supplement the number of arms, the Marakwets also bought arms illegally.

Describing the superior Pokot tactics, Father Walters narrates how one day his father, a Mr. Kibet, a member of Marakwet County Council, was nearly killed when the Pokots attacked him. First they tactically surrounded the nearby GSU camp using a few sentries to pin down the GSU while the rest of the raiders attacked the villagers. This was superior tactics beyond normal cattle rustling. ${ }^{29}$ A research on small arms and insecurity in the north rift by Security Research and Information Centre (SRIC) revealed that the pastoralist communities in this region had over 127,519 illegal arms. There were 66,239 arms in Turkana, 36,937 in West Pokot, 16,478 in Samburu, 7,773 in East Baringo and only 92 in Marakwet. The report also revealed that some of these arms were more sophisticated than those held by the state security officers. ${ }^{30}$ This has led

25 Interview with Mr. Gicheru, DOI, Marakwet district, 24 Sept 2007 at Marakwet district headquarters, Kapsowar.

26 See for example Human Rights Watch, 2002 and Mwachofi Singo, Francis Wairagu and JAN Kamenju, Peace, Security and Development: An Agenda for the North Rift Region of Kenya (Nairobi: SRIC, 2001).

$27 \quad$ Interview with a Mr. Toyok at Kapenguria, 29 Sept 2007.

28 Interview with Mzee Joshua Lang'at, 77 years old and a member of a two year old Marakwet Council of Elders, 20 Sept 2007.

$29 \quad$ Interview with Mr. Walters Kibet, a Catholic priest at Kapsowar Catholic Parish, op. cit. Born and brought up at Chesogoch, a junction Shopping Centre just a few kilometers from Tot.

30 J. A. N. Kamenju, M. Singo and F. Wairagu, Terrorized Citizens: Profiling Small arms and Insecurity in the North Rift of Kenya (Nairobi: Security Research and Information Center-SRIC 2003). 
to an increase in cases of banditry and cattle rustling. Crimes such as car jacking, personal crime and poaching have increased since the government security agencies are overwhelmed. ${ }^{31}$

\section{The Facilitating Insecurity Environment}

\section{Banditry}

Besides the harsh environment that characterizes North-western Kenya, there are also waves of activities that border on crime. The issues of banditry, underdevelopment and ethnicity compound the lawlessness that inhibits provision of security. The basic insecurity problems in North-western Kenya are best conceptualised in the context of the relationship between borders, frontiers and violence. While some attention has been focused on territorial borders, little has been given to the problem of internal boundaries. The internal borders separate different nomadic communities that know and respect no territorial borders. ${ }^{32}$ The problem of insecurity then becomes inter linked throughout the conflict system. The diffusion of insecurity has generated a wave of internally displaced persons who have become a serious security problem in the conflict system by providing a ready source of small arms carried across the borders into Kenya.

Banditry and cattle rustling are major security issues among pastoral communities in Kenya. Banditry affects and crosses the border of all the states in eastern Africa. The responses of the governments have been to send in the military and police officers, who seem to be overwhelmed by fire power of the bandits. ${ }^{33}$ The Marakwet and Pokot communities have, for a long time, engaged in banditry and cattle rustling with little government interventions. ${ }^{34}$ Because the areas are frequented by bandits, there are fewer development activities compared to other parts of Kenya. ${ }^{35}$ Marakwet district for instance, has a large population, but there is no tarmac road to serve this population indicating biased political policies and apparent economic marginalization of pastoralists from mainstream national development.

\section{Social underdevelopment}

Because of insecurity, schools and hospitals are unsafe and insecure for the public. Primary schools such as Ngenyireel and Murkutwo had to be relocated to new sites picked as defensive positions. $^{36}$ The changes of school locations have serious negative impacts on school attendance.

31 C. Jefferson and A. Muchai, Kenya Crime Survey 2000 (Nairobi: Security Research and Information Centre SRIC 2003).

32 M. Mwagiru, "Borders, Frontiers and Conflict In the Horn of Africa: Some Preliminary Hypothesis", Prepared for "The Horn of Africa Between Post-War Reconstruction and Fragmentation" an Expert Workshop By The Development and Peace Foundation, op. cit.

33 Ibid, and The East African Standard, (Nairobi) April, 4 (2001). Currently, there has been improvement in government involvement in development. An exercise Dumisha Amani, a military exercise combined with development agenda is currently going on in the north rift. It intends to open up the North Western Kenya through development.

$34 \quad$ USAID, Greater Horn of Africa, Peace, Building Project Assessment and Programmatic Recommendations op cit.

35 L. Barasa and F.Oluoch, Marakwet District, Kenya Human Rights up Date Issue 8-op cit. Even though there are many other factors that contribute to underdevelopment, insecurity is a major contributing factor.

36 Interview with Mwalimu Mercy Jerop, a volunteer teacher, narrates how the community has adopted the new way of life after several attacks, 27 Sept 2007. 
The number of children in schools is generally low. Although feeding programmes have been launched to keep the children in schools, the distances to schools is a problem. ${ }^{37}$ Apart from the isolated schools, there is only one health facility in the entire area, Tot health centre.

The border between Pokot and Marakwet has a number of roads. Most of these roads are, however, impassable creating a challenge for motorists and security agencies. During cattle raids when alarm is raised, the government security agents, especially the police, the army and GSU are slowed down by the poor roads leading to serious loss of life and property. Besides the poor state of roads, telephone communication is only by mobile providers; Safaricom or Zain, facilities that were only installed recently in the year 2007. The facilities come at a price though as the costs of owning, maintaining and making telephone calls are too high for the inhabitants. The poor infrastructure implies weak security systems and low economic activities. It also raises transportation costs which increase the prices of commodities excessively and make it hard for shopkeepers to stock a variety of commodities. For example, in Tot and other market centres in Marakwet and Pokot, a 300ml bottle of soda costs about ten to fifteen shillings more than the official company retail price.

Credit facilities that could assist in economic development are equally lacking in this region. For the few such as the Kenya Commercial Bank micro-finance facility, difficult terms and conditions have made it impossible for the people in this region to access credit. For the Marakwet who grow sorghum, finger millet, cassava, mangoes and bananas, market for their produce is a major constraint to their efforts in economic development. Mangoes, for example, are perishable and can only be consumed within a short period as there is no processing factory in this location. The closest and probably the place where mangoes are sold in bulk is in Nakuru and Nairobi, a distance of approximately $300 \mathrm{~km}$ and $470 \mathrm{~km}$ respectively. ${ }^{38}$

\section{Negative Ethnicity}

Negative ethnicity makes the Pokot and the neighbouring communities to live in constant mistrust. The Marakwet are always suspicious that at a certain point, the Pokot may attack and destroy their crops and property. Even though this is the case, there are a number of efforts being made to ensure that the two communities are integrated properly. Most of the efforts are aimed at building confidence between the communities. In one village, Murkutwo, a boarding secondary school has been built to admit students from both the Pokot and Marakwet communities to allow them integrate and understand each other fully. ${ }^{39}$

Negative ethnicity is highly rooted in this part of the country, yet the government security agencies - GSU, Kenya Police or Kenya Armed Forces,-have not been effectively employed to restore peace. This is possibly because the political leadership has in the past been using the divisive ethnic strategy to hold on to power. The Kenyan Human Rights Commission Report

37 Interview with Tot area Chief Mr. Maina who narrates that the school feeding programme encourages children to go to school, albeit with difficulty.

38 The communities cannot afford to transport their farm products at all and that is why Mr. Joshua Yatich of Sambalat village dreams of a time when there will be a mango juice making factory, interview, 1 Oct 2007.

39 Interview with Mr. William Chemengut Chepkinyey, head teacher, Queen of Peace Secondary School, 22 Sep 2007. 
recorded the massacre against the Marakwet in North-western Kenya, as an attempt by the then ruling party, KANU, to gain back political ground that it had lost since $1992 .{ }^{40}$ The infamous March 12, 2001 massacre of the Marakwets by a large group of Pokots armed with sophisticated fire arms, in which more than fifty people were killed, was part of the ruling party elites' political scheme to cling to power and sustain its hold in the Rift Valley Province ahead of the 2002 general elections. $^{41}$

\section{Conclusions}

The interaction between the environmental constraints, traditions, politics and the acquisition of fire arms creates an extremely volatile situation in North-western Kenya. The incumbent cattle rustling and banditry coupled with hostile climatic conditions and economic marginalization makes it extremely difficult to enforce security. North-western Kenya is remote and far removed from the central government leadership. In order to provide security to the frontier citizens, the government could provide these communities with transitional security, one that accompanies the communities as they traverse their frontiers. This could be enforced by educating and sensitizing the communities on the benefits peace.

In order to access the communities and deal with the bandits conclusively, the infrastructure needs to be improved. The presence of small arms and their trafficking have changed the nature and practice of cattle rustling. However, for the north-western Kenya, communities require the weapons to protect their animals against wild animals and the vagaries of the semi desert. The communities should be sensitized about the proper use of the weapons though. Other economic activities need to be initiated to empower the inhabitants of this region who rely fully on their cattle for survival. One may be tempted to argue that, provision of water could alleviate the suffering of the Pokot. But this is not the case because, while the Kenyan Government has been sinking boreholes and building water dams with intent to provide water, the banditry and cattle rustling still persists. Improving the general economic well being of the region must be a top priority to be addressed on an equal footing with the problem of pasture and water.

\section{References}

Barasa L. and F.Oluoch, Marakwet District, Kenya Human Rights up Date Issue 8.

Boking M., (1998) Outline of Pre-colonial Eastern Pokot History, (Institute of African Studies: University of Nairobi).

Deng F., Sadikiel Kimaro, (1996)Terrence Lyons, Donald Rothchild, and I. William Zartman, Sovereignty as Responsibility: Conflict Management in Africa (Washington D.C.: The Brookings Institution), pp. 1-33.

\footnotetext{
40 C. Njoroge, 'Attacks against Marakwet Planned’ Report: cnjoroge/ AFRICANEWS (2001).

41 The attacks on the Pokot is a representation of the other nomadic communities and in essence therefore, is a reflection that attacks and counter-attacks do occur from each of the communities. It follows therefore that the Pokot are also attacked by the Marakwet, Turkana, Samburu and Toposa on different occasions.
} 
Human Rights Watch, 2002.

Jefferson C. and A. Muchai, (2003) Kenya Crime Survey 2000 (Nairobi: Security Research and Information Centre - SRIC).

Kahl, C. H., (2000) States, Scarcity and Civil Strife in Developing World (Princeton: Princeton University Press), pp 117-162:123.

Kamenju, J. A. N., M. Singo and F. Wairagu, (2003) Terrorized Citizens: Profiling Small arms and Insecurity in the North Rift of Kenya (Nairobi: Security Research and Information CentreSRIC).

Kuvita K., (1983) 'Material Culture of the Pokot in Kenya: With Special Reference to Circulation of Articles’ In African Study Monograph Supplementary Issue No. 3.

Mwagiru M., (2000), 'Borders, Frontiers and Conflict in the Horn of Africa, Some Preliminary Hypothesis 'Prepared for The Horn of Africa Between Post-War Reconstruction and Fragmentation' An Expert Workshop held by The Development and Peace Foundation, on August 29 - September 2, in Bad Honnef, Germany.

Mwagiru M., (2003) Peace and Conflict management in Kenya (Nairobi: Pann Printers).

Njoroge C., (2001)‘Attacks against Marakwet Planned’ Report: cnjoroge/AFRICANEWS

OECD/DAC, (2008) The Principles for good international engagement in fragile states and situations, Paris, 2007 and OECD/DAC, Concepts and Dilemmas of state building in fragile situations, Off-Print of the Journal of Development, pp 17-18.

Onyango, O. C., (2000) 'Territorial Claim as the Model Determinant of Inter-State Conflicts Between Ethiopia and Somalia, 1960-1991' in P. Godfrey Okoth \& Bethwell A. Ogot, (ed.), Conflict in Contemporary Africa (Nairobi: Jomo Kenyatta Foundation), pp. 82-93:82.

Singo M., Francis Wairagu and JAN Kamenju, (2001) Peace, Security and Development: An Agenda for the North Rift Region of Kenya (Nairobi: SRIC, 2001).

Taylor, P.J., (1985) Political Geography: World Economy, Nation State and Locality (New York: Longman)

The East African Standard, (Nairobi) April, 42001.

The Editor, Disaster Relief Organization; DisasterRelief.Org. http://www.disasterrelief.org accessed on 6 September 2010.

The OAU Charter Article 3(2).

The Standard, Nairobi, Kenya Friday, September 3, 2010, p.13.

The Washington Post July 8, 2001.

Touval S., (1972) The Boundary Politics of Independent Africa (New Haven: Harvard University Press). 
USAID, (2002), Greater Horn of Africa Peace Building Project: Assessment and Programmatic Recommendations: Addressing Pastoralist Conflict in the Karamoja Cluster of Kenya, Uganda and Sudan, (Washington D.C: Management Systems International). 